BUSTANUL FUQAHA: Jurnal Bidang Hukum Islam

Vol. 1, No. 3 (2020) : Hal. 505-515

Website: https://journal.stiba.ac.id

\title{
LATAR BELAKANG SOSIAL LAHIRNYA MAZHAB ḤAMBALI
}

\author{
Rahmat Abd. Rahman \\ Sekolah Tinggi Ilmu Islam dan Bahasa Arab (STIBA) Makassar \\ Email: rahmatar09@stiba.ac.id
}

\begin{abstract}
Keywords :
Ahmad bin Hambal, School of Thought, Background, Social, Fiqh
\end{abstract}

\begin{abstract}
The fatwas or fiqh views of scholars in the past were basically born as a reaction to social phenomena that emerged in society. Not only looking at the problems of society in general, but it also responded to government's or the caliph's policies in their time. Imam Ahmad bin Hambal is one of the great scholars whose school of thought until this day has developed throughout the world. It is undeniable that the socio-political background was the forerunner of the growth and development of the Hambali School to the digital era today. For this reason, the purpose of this study is to determine the social background of the emergence of the Hambali School and the influence or correlation of social life at the time of Imam Ahmad bin Hambal with his views in the field of fiqh and ushul fiqh. The research method that used is qualitative descriptive approach with content analysis techniques and library research. Apart from that, essentially, this research applied historical and theological approaches. The results showed that social background seemed to influence the emergence of the Hambali School, among others; theological disputes, political conditions, and the development of sciences (dirasah Islamiyah) were quite rapid in his time, it indirectly had implications to his views in the field of fiqh and ushul fiqh. The implications of this research indicate that scholars should maintain the social conditions of their society, particularly in applying the syar'i propositions, so that the fiqh opinions of Allah $\square$ scholar should not be seen only from a pure discussion of its syar'i propositions.
\end{abstract}

$A B S T R A C T$

Kata kunci :

Ahmad bin Hambal, Mazhab, Latar, Sosial, Fikih

\begin{abstract}
Fatwa-fatwa atau pandangan fikih para ulama di masa silam pada dasarnya lahir sebagai sebuah reaksi atas fenomena sosial yang mengemuka di masyarakat. Bukan hanya melihat persoalan masyarakat pada umumnya, akan tetapi juga menanggapi kebijakan pemerintah atau khalifah di masanya. Imam Ahmad bin Hambal adalah salah seorang ulama besar yang sampai hari ini mazhabnya berkembang di seluruh penjuru dunia. Tidak dipungkiri bahwa latar belakang sosial politik adalah cikal bakal tumbuh dan berkembangnya Mazhab Hambali hingga di era digital hari ini. Untuk itu, tujuan dari penelitian ini adalah untuk mengetahui latar belakang sosial lahirnya Mazhab Hambali dan pengaruh atau korelasi kehidupan sosial di masa Imam Ahmad bin Hambal terhadap pandangan-pandangannya di bidang fikih dan usul fikih. Metode penelitian menggunakan pendekatan deskriptif kualitatif dengan teknik analisis konten dan riset kepustakaan. Selain itu, secara esensial, penelitian ini menerapkan pendekatan historis dan teologis. Hasil penelitian menunjukkan bahwa latar belakang sosial tampak mempengaruhi lahirnya Mazhab Hambali antara lain; perselisihan teologis, kondisi politik, dan perkembangan ilmu
\end{abstract}


pengetahuan (dirasah Islamiyah) yang cukup pesat di masanya, sehingga secara tidak langsung berimplikasi pada pandanganpandangan beliau di bidang fikih dan usul fikih. Adapun implikasi penelitian ini menunjukkan bahwa seyogianya para ulama hendaknya menjaga kondisi sosial masyarakatnya, khususnya dalam penerapan dalil syar'i, sehingga pendapat-pendapat fikih seorang ulama tidak boleh dilihat hanya dari pembahasan dalil syar'i secara murni.

\section{PENDAHULUAN}

Fikih adalah kemampuan menalar suatu dalil sehingga menghasilkan hukum. Menurut Ibnu Taimiyah, fikih adalah kemampuan memahami yang terbaik dari dua kebaikan atau yang terburuk dari dua keadaan. ${ }^{1}$ Seorang fakih adalah yang mampu memahami keinginan Allah swt. lewat dalil-dalil ilahiyah dan menerapkannya dalam kondisi kemasyarakatan. Terdapat korelasi yang kuat antara hukum-hukum normatif yang dikandung oleh dalil dengan kondisi sosial suatu masyarakat, dan bagi seorang fakih hal itu merupakan pertimbangan dalam penalarannya.

Imam Ahmad bin Hambal adalah salah seorang fakih yang hidup di abad ke-3 hijriah, fatwa dan pendapat-pendapat fikihnya tidak luput dari kondisi yang ada di sekelilingnya. Hal itu merupakan penjabaran dari dalil dan kaidah-kaidah usul fikih yang telah pernah disampaikan oleh ulama Islam yang ada sebelumnya, seperti Abu Hanifah, Malik bin Anas dan al-Syafi'i rahimahumullahu di samping kaidah yang Imam Ahmad cetuskan sendiri.

Abad ke-2 hingga ke-5 hijriah adalah merupakan zaman keemasan ilmu pengetahuan, khususnya disiplin ilmu syar'î. Masing-masing dari bidang fikih, hadis, tafsir Al-Qur'an dan Bahasa Arab yang mengalami perkembangan yang sangat pesat. Tadwin (pengumpulan) dan ta' Tif (penulisan) atau kodifikasi ilmu pengetahuan begitu gencar, di bidang fikih berdiri empat mazhab besar yaitu Hanafiyah, Mālikiyah, Syāfi'iyah dan Ḥanābilah di samping mazhab fikih lainnya seperti Rāhawiyah, Śauriyah dan lain-lain. Di bidang hadis, terdapat al-Bukhāri dan Muslim bin al-Hajjāj yang menghimpun hadis-hadis sahih, di bidang tafsir AlQur' an terdapat Abu Ja'far al-Ṭabarī, di bidang Naḥwu terdapat 'Amru bin Us̀mān al-Fārisì atau yang terkenal sebagai Sibawaih.

Perkembangan ilmu pengetahuan ini juga diliputi oleh pergolakan politik di kalangan Bani Umayyah dan Bani 'Abbāsiyah. Sekalipun Bani 'Abbāsiyah memimpin khilafah pada abad ke-3. Namun, perselisihan di kalangan mereka

'Ahmad bin 'Abd. al-'Azis al-Ḥulaybī, Ușūl al-Hukm 'Alā al-Mubtadi'ah 'Inda Syaikh al-Islām Ibn Taimiyah, Jilid I (Cet. I; Doha: Wizārah al-Awqāf wa al-Syu'ūn al-Islāmiyah, 1417 H), h. 15. 
sendiri juga tetap sengit. Perseteruan antara dua saudara al-Amin dan al-Ma'mūn menjadi warna tersendiri pada rezim tersebut, hingga akhirnya dimenangkan oleh al-Ma'mūn yang dilantik menjadi khalifah pada tahun $198 \mathrm{H}$.

Keadaan politik menjadi lebih stabil sejak khiläfah dijabat oleh al-Ma'mūn, namun pada saat yang sama terjadi pergolakan lain, yaitu di bidang teologi. Khalifah al-Ma'mūn adalah pendukung pemikiran Muktazilah yang lebih mengedepankan logika dari dalil syar'i dalam segala hal, khususnya dalam persoalan teologi (akidah). Hal ini mendapat penentangan keras dari para ulama Ahli sunah waljamaah sebab pemikiran tersebut sangat sering bertentangan dengan konsep akidah yang dalilnya begitu jelas di dalam Al-Qur'an atau hadis. ${ }^{2}$ Contohnya adalah sifat al-Kalām, di dalam Al-Qur'an sifat al-Kalām adalah salah satu sifat Allah swt. seperti yang terdapat pada Q.S. al-Nisā'/4: 164,

\section{وَكَلَّمَ اللَّهُهُ مُوسنَى تَكْلِيمًا [النساء : 164]}

Terjemahnya: Dan Allah telah berbicara kepada Musa secara langsung. ${ }^{3}$

Kaum Muktazilah menolak sifat al-Kalām dengan dalih bahwa Allah swt. tidak serupa dengan makhluk-Nya. Jika Allah swt. memiliki sifat al-Kalām, maka berarti Ia serupa dengan manusia yang memiliki sifat berbicara. Kaum Muktazilah menolak lafaz-lafaz Al-Qur'an sebagai firman Allah swt., tetapi mereka menganggapnya sebagai makhluk ciptaan Allah swt. Hal ini ditentang sangat keras oleh para ulama Ahli sunah waljamaah pada saat itu, termasuk Ahmad bin Hambal rahimahumullahu.

Mazhab Hambali merupakan kumpulan dari pemikiran-pemikiran fikih dan fatwa-fatwa Imam Ahmad bin Hambal. Hasil ijtihad tersebut dibangun atas pandangan-pandangan usul fikih terhadap dalil yang terdapat di dalam Al-Qur'an dan hadis, seperti: pemakaian hadis mursal (riwayat seorang täbi'i langsung dari Rasulullah saw.). Ijtihad fikih tersebut tidak dapat lepas dari kondisi sosial yang ada di sekelilingnya, sebab salah satu syarat atas seorang fakih adalah mengetahui realitas masyarakatnya dalam penerapan suatu hukum. ${ }^{4}$

Ketidakpedulian terhadap realitas masyarakat akan membuat fatwa atau ijtihad seorang ulama tidak sempurna dan cenderung keliru, demikian pula ijtihad yang dilontarkan ke tengah masyarakat dan tidak menjaga realitas yang terjadi, akan cenderung menimbulkan kontroversi dan kondisi yang kontra produktif. Oleh

\footnotetext{
²Mannā' al-Qaț̣ān, Tārikkh al-Tasyrī' al-Islāmīi(Cet. I; Riyāḍ: Maktabah al-Ma’ārif, 1992), h. 378.

${ }^{3}$ Departemen Agama Republik Indonesia, Alquran dan Terjemahnya (Medina: Mujamma' al-Malik Fahd li Ṭibā'at al-Muṣhaf al-Syarif, 1418 H), h. 415.

${ }^{4}$ Lihat Ibnu Qayyim al-Jauziah, I'lām al-Muwaqqi'in' 'An Rabb al-'Ālamin', Jilid V (Cet. II; Beirut: al-Maktabah al-‘Așriyah, 1417 H), h. 59.
} 
karena itu, latar belakang sosial mazhab fikih yang telah ada di dunia Islam ini menarik untuk dikaji agar dapat dikembangkan di kondisi kekinian. Untuk itu, penelitian ini mengerucutkan rumusan masalahnya yaitu: 1) Bagaimanakah latar belakang sosial lahirnya mazhab Hambali?; 2) Bagaimanakah pengaruh kehidupan sosial di masa Imam Ạ̣mad bin Hambal terhadap pandangan-pandangannya di bidang fikih dan usul fikih?.

\section{PEMBAHASAN}

\section{Latar Belakang Sosial Lahirnya Mazhab Hambali}

Kehidupan sosial memiliki pengaruh yang besar terhadap pandangan seorang manusia, karena suatu pandangan terbentuk dari persepsi terhadap dalil normatif dan realitas yang dirasakan. Menurut Ibnu al-Najjār al-Fattūhị:

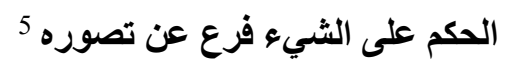

Artinya: Hukum atas sesuatu adalah bagian dari persepsi terhadapnya.

Mazhab Hambali adalah nisbah kepada Imam Ahmad bin Hambal dan merupakan hasil-hasil ijtihad fikih dan fatwa-fatwa semasa hidupnya. Pandanganpandangan tersebut mulai Imam Ahmad sampaikan ketika berusia 40 tahun yaitu di tahun $204 \mathrm{H}$. Imam Ahmad bin Muhammad bin Hambal dilahirkan pada tahun $164 \mathrm{H}$ di kota Baghdād, lalu bersama keluarganya pindah ke kota Baṣrah ketika kakeknya diangkat menjadi walikota Sarkhas di wilayah Khurāsān pada era khilafah Umawiyyah. Namun, karena kakeknya ikut bergabung dalam kelompok 'Abbasiyah setelah itu, mereka pun dikucilkan dan diintimidasi hingga akhirnya keluarganya memutuskan untuk kembali ke kota Baghdād. ${ }^{6}$

Imam Ạ̣mad bin Hambal ditingal mati oleh ayahnya sejak berusia 3 tahun, maka ia dirawat oleh ibunya dan dikenalkan pada ilmu pengetahuan sejak dini. Awalnya beliau menekuni bidang fikih dari al-Qāội Abu Yusuf, murid ternama dari Imam Abu Hanifah, namun beliau akhirnya lebih tertarik kepada ilmu hadis dan mempelajarinya dari Imam al-Syāfi' 'i secara langsung. Selain itu, Ahmad bin Hambal juga pernah belajar ke negeri Yaman dari Imam ‘Abdurrazāq al-Șana'ānī bersama kedua sahabatnya, yaitu Yahyā bin Ma’ìn dan Isḥāq bin Rāhawaih. Demikian pula dengan negeri-negeri lainnya, telah pernah dikunjungi oleh Ahmad

${ }^{5}$ Muḥammad bin Aḥmad al-Fattūḥī, Syarh al-Kawkab al-Munīr, Jilid I (Cet. II; Mekkah: Maṭābi’ Ummu al-Qurā, 1413 H), h. 50.

${ }^{6}$ Al-Qatțān, op.cit., h. 381. 
bin Hambal dalam rangka mempelajari ilmu syar'ī sebagaimana kebiasaan para ulama Islam. ${ }^{7}$

Setelah lama mengelilingi dunia dalam rangka menuntut ilmu, akhirnya Imam Ạ̣mad bin Hambal menetap kembali di kota Baghdād dengan motivasi menyampaikan ilmu tersebut kepada umat manusia. Hasil-hasil ijtihad Imam Ahmad dapat diterima oleh murid-muridnya dengan baik, sehingga mereka pun menyebarkan Mazhab Hambali dan mengakibatkan banyaknya orang yang selalu hadir dalam setiap majelis pengajiannya. ${ }^{8}$ Muncul dan tersebarnya pendapatpendapat fikih Imam Ahmad bin Hambal juga disebabkan oleh latar belakang sosial di zamannya. Latar belakang sosial itu dapat dirangkum dalam beberapa poin, yaitu:

\section{Perselisihan Teologis}

Era kehidupan Imam Ạ̣mad adalah periode di mana terjadinya perselisihan teologis yang sangat kuat. Perselisihan itu melibatkan kelompok Ahli sunah waljamaah dan kelompok Muktazilah bahkan hingga Syi'ah. Perselisihan antar kelompok-kelompok ini tidak lepas dari gerakan penerjemahan buku-buku filsafat yang diinstruksikan oleh Khalifah al-Ma'mūn. Khalifah al-Ma'mūn sendiri adalah penganut pemikiran Muktazilah yang memaksakan pendapatnya atas rakyat dalam permasalahan-permasalahan teologis, seperti tentang Al-Qur'an adalah makhluk dan bukan firman Allah. ${ }^{9}$

Muktazilah adalah ajaran yang bersendikan nalar murni (rasio) buat memahami permasalahannteologis di dalam Islam. ${ }^{10}$ Ajaran ini bercorak filsafat yang memprioritaskan daya nalar dalam memahami dan menjabarkan hakekat ketuhanan, sehingga terkadang mengabaikan dalil-dalil Al-Qur'an dan hadis. Contohnya pengakuan tentang kedudukan seorang pelaku dosa besar di dunia, tidak beriman dan tidak kafir (al-manzilah bayna al-manzilatayn) tetapi di akhirat tempatnya adalah kekal di neraka. Dalih kaum Muktazilah adalah kemustahilan berkumpulnya antara iman dan kekufuran dalam diri seseorang karena iman itu satu dan tidak dapat terbagi-bagi.

Keimanan di dalam Al-Qur'an dan hadis disebutkan tetap bertahan sekalipun pelakunya melakukan dosa besar, misalnya yang terdapat di dalam Q.S. al-Hujurāt/ 49: 9

\footnotetext{
359-360.

${ }^{7}$ Ismā'ìl ibn 'Umar ibn Kas̄īr, al-Bidāyah wa al-Nihāyah, Jilid X (Beirut: Dār al-Ihyā al-Turās̀ al-'Arabi, t.th), h.

${ }^{8}$ Al-Qațāan, op.cit., h. 381-382.

'9al-Juhanī, Māni' bin Hammād, al-Mawsū'ah al-Muyassarah fí al-Adyān wal Mażāhib wal Ahzāb al-Mu'ạṣirah, Jilid I (Cet. III; Riyāḍ: WAMY, 1418 H), h. 132.

${ }^{10}$ Ibid.
} 


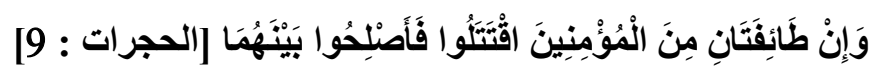

Terjemahnya: Dan jika ada dua golongan dari orang-orang mukmin berperang maka damaikanlah antara keduanya. ${ }^{11}$

Allah swt. tetap menamakan mereka sebagai kaum mukminin sekalipun terlibat dalam perang saudara, padahal peperangan antar sesama kaum mukminin adalah dosa besar. Demikian pula di dalam hadis yang diriwayatkan dari Abu Żarr al-Ghifāri ra. bahwa Rasulullah saw. bersabda:

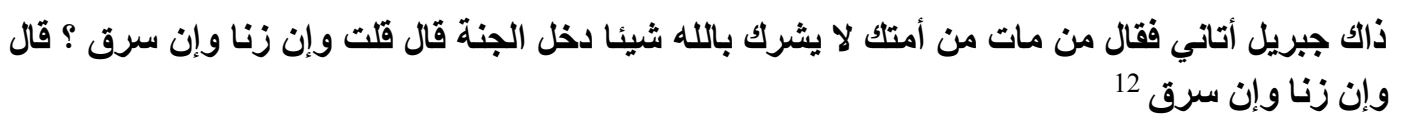

Artinya: Malaikat Jibril tadi menjumpaiku dan berkata: siapa pun di antara umatmu yang mati dalam keadaan tidak berbuat syirik maka pasti ia masuk ke syurga. Aku pun bertanya: "Walaupun ia berzina atau mencuri ?". Ia menjawab: walaupun ia berzina atau mencuri. (H.R. Muslim).

Perbuatan zina dan mencuri adalah dosa yang besar, namun hal itu tidak membatalkan keislaman seseorang. Berdasarkan hadis ini, hanya perbuatan syirik yang dapat membuat seseorang keluar dari Islam.

Pemikiran kaum Muktazilah mendapatkan penentangan dari kalangan ulama Ahlusunah di zaman itu. Mereka menganggap bahwa pemahaman tersebut menyimpang dari tuntunan wahyu, sebab lebih memberikan prioritas kepada nalar daripada dalil. Padahal dalil sya'i-lah yang semestinya menjadi acuan dalam menjelaskan tentang agama. Ahlusunah dengan ini bukan menolak penggunaan nalar di dalam agama, namun nalar yang benar adalah yang mengikuti maksud dan tujuan dalil bukan menentangnya apalagi sebaliknya.

Imam Ạ̣mad bin Hambal adalah salah satu ulama Ahli sunah waljamaah yang sangat tegas terhadap pemikiran Muktazilah. Imam Ahmad tidak mau berkompromi sedikit pun terhadap hasil-hasil pemikiran mereka yang tidak benar sekali pun didukung oleh Khalifah al-Ma'mūn dan mengancam akan menghukum siapa saja yang tidak mau menerimanya. Akhirnya Imam Ahmad harus berhadapan dengan khalifah dalam perkara apakah Al-Qur'an makhluk ciptaan Allah swt. atau firman-firmanNya?.

Khalifah al-Ma'mūn sebagaimana kaum Muktazilah beranggapan bahwa Al-Qur'an adalah makhluk ciptaan Allah swt., sebab Ia tidak memiliki sifat alKalām, sedangkan Imam Ahmad sebagaimana ulama Ahlusunah lainnya mengakui

\footnotetext{
${ }^{11}$ Departemen Agama Republik Indonesia, op.cit, h. 846.

${ }^{12}$ al-Naisābūri, Muslim ibn al-Ḥajjāj, al-Ṣahīh Ma’a al-Nawawi, Kitāb al-Īmān, Bāb Man Māta Lā Yusyrik Billahi Syai’an, Jilid II (Cet. I; Beirut: Dār al-Kutub al-'Ilmiyah, 1415 H), h. 81.
} 
bahwa Al-Qur'an merupakan fiman Allah swt. secara langsung yang didengar oleh malaikat Jibril dan disampaikan kepada Nabi Muhammad saw. Ahlusunah mengakui bahwa Allah swt. memiliki sifat al-Kalām, namun tidak sebagaimana makhluk-makhluknya.

Atas perbedaan ini, Imam Ahmad mendapatkan hukuman yang berat dari khalifah al-Ma'mūn bahkan oleh 2 (dua) khalifah yang datang berikutnya, yaitu alMu'tașim dan al-Wäsiq yang memiliki pemahaman sama dengan al-Ma'mūn. Hukuman berupa kurungan penjara dan cambuk bahkan ancaman hukum mati, tidak menyurutkan sikap Imam Ahmad hingga tiba periode al-Mutawakkil dan membebaskannya dari segala tuduhan. ${ }^{13}$

Secara teologis, Mazhab Hambali adalah pengusung Manhaj Ahli sunah waljamaah pada zamannya. Sekali pun bertentangan dengan kebijakan pemerintah yang ada, namun masyarakat lebih memilih bersama Imam Ahmad dalam keteguhan prinsipnya daripada mengikuti pemikiran Muktazilah yang didukung oleh negara. Namun, Imam Ahmad juga tidak berpikir politis dengan menggalang massa buat mengubah kemungkaran yang ada menurut beliau, karena manhaj Ahli sunah waljamaah lebih mengedepankan kepentingan umum dan selalu berupaya tidak mengorbankan jiwa umat manusia.

\section{Kondisi Politik}

Konstelasi politik antara Bani Umayyah dan Bani 'Abbāsiyah akhirnya berakhir dengan kemenangan Bani 'Abbāsiyah di pertengahan kedua abad ke-2 Hijriah. Tetapi perselisihan internal pada rezim 'Abbāsiyah sendiri juga tak kalah sengitnya, Al-Ma'mūn dilantik menjadi khalifah setelah melakukan kudeta atas saudaranya al-Amin pada tahun $198 \mathrm{H}$ dan kondisi politik pasca pelantikan itu relatif lebih stabil. Kekuasaan al-Ma'mūn berakhir hingga wafatnya pada tahun $218 \mathrm{H}$ dan yang menjadi khalifah setelah itu adalah saudaranya, yaitu al-Mu'tașim, kemudian digantikan oleh anaknya al-Wāșiq pada tahun $227 \mathrm{H}$, lalu diganti oleh saudaranya al-Mutawakkil pada tahun $232 \mathrm{H}^{14}$

Gonjang-ganjing politik ini juga menimpa keluarga Imam Ahmad bin Hambal. Kakeknya, yaitu Hambal di masa pemerintahan Bani Umayyah diangkat menjadi walikota Sarkhas di wilayah Khurāsān, namun karena keputusannya bergabung dengan kelompok 'Abbāsiyah akhirnya jabatannya dicopot dan dikucilkan. Akhirnya mereka kembali ke tempat asalnya yaitu di kota Baghdād yang sebelumnya hidup di kota Bașrah dan Marwu. Namun, hal tersebut juga berdampak positif terhadap Imam Aḥmad karena dapat berguru kepada banyak

\footnotetext{
${ }^{13} \mathrm{Ibnu}$ Kasiir, al-Bidāyah, h. 364-365

${ }^{14}$ Ibid., h. 265-341.
} 
ulama di sana, di antaranya adalah Imam al-Syāfi' '’, al-Qāọ̣i Abu Yusuf, Wakỉ' bin al-Jarrāh dan Isma'îl bin 'Ulayyah. ${ }^{15}$

Kondisi politik ini juga berlanjut hingga rezim 'Abbāsiyah, sebagaimana disampaikan dahulu bahwa kepemimpinan Khalifah al-Ma'mūn telah mendukung penyebaran pemikiran Muktazilah dan menghukum siapa saja yang menentangnya. Bahkan Khalifah pun memerintahkan penerjemahan buku-buku filsafat Yunani dan Romawi ke dalam Bahasa Arab sehingga menyebabkan tumbuh dan berkembangnya pemikiran-pemikiran dan amalan-amalan yang menyimpang dari tuntunan wahyu ilahi. Sebagai contoh adalah instruksi Khalifah untuk bertakbir dengan membesarkan suara setiap selesai menunaikan salat lima waktu. ${ }^{16}$

Perbuatan ini tidak pernah dicontohkan oleh Rasulullah saw., para sahabat dan kaum muslimin sebelumnya, namun karena pengaruh politik dari instruksi khalifah, maka akhirnya amalan ini dilaksanakan di masjid-masjid di kota Baghdād. Sekalipun pemikiran-pemikiran dan amalan-amalan tersebut mendapatkan penentangan dari kalangan ulama Ahli sunah waljamaah. Pengaruh politik ini sangat berimbas pada mazhab yang dinisbahkan kepada Imam Ahmad bahkan namanya pun menjadi Mazhab Hambali, mengambil nama kakeknya karena kemasyhurannya.

\section{Perkembangan Ilmu Pengetahuan}

Kota Baghdād adalah kota ilmu pengetahuan dan kota para ulama besar. Hingga Imam Abu Bakar Aḥmad bin 'Ali yang terkenal dengan nama al-Khațīb alBaghdādi (392-465 H) menyusun biografi semua ulama di segala bidang ilmu pengetahuan yang pernah tinggal di kota tersebut hingga masanya, baik yang menetap atau yang sekedar singgah. Biografi tersebut dihimpun dalam kitab yang berjudul Tärikh Baghdād Dār al-Salām dan manuskripnya mencapai sepuluh ribu halaman. ${ }^{17}$

Para ulama yang ada di zaman tersebut pun terkenal dengan produktivitasnya dalam menghasilkan karya-karya ilmiah. Di bidang fikih dan usul fikih, Imam al-Syāfi' $\bar{i}$ menulis kitab al-Risālah dan al-Umm, di bidang hadis terdapat Muhammad bin Humaid (w. 230 H) menyusun kitab al-Musnad, atau Imam al-Bukhāri (w. 256 H) yang menyusun kitab al-Jāmi' al-Sahịh, di bidang teologi terdapat Abu Bakar Muhammad bin Khuzaimah (w. $311 \mathrm{H}$ ) yang menulis kitab al-Tauhīd atau Imam Hibatullah al-Lālakä (w. $418 \mathrm{H}$ ) yang menulis kitab Syarah Ușūl I'tiqād Ahlu al-Sunnah Wa al-Jamā'ah, di bidang tafsir Al-Qur'an

${ }^{15}$ Al-Juhanī, op.cit., h. 132.

${ }^{16} \mathrm{Ibnu}$ Kasīir, op.cit., h. 296.

${ }^{17}$ Salih Ahmad al-'Ali, Muqaddimah Kitab Tarikh Baghdad li al-Imam al-Khatib al-Baghdadi (Cet.I; Beirut: Dar al-Garb al-Islami, 2001), h.6. 
BUSTANUL FUQAHA: Jurnal Bidang Hukum Islam

Vol. 1, No. 3 (2020) : Hal. 505-515

Website: https://journal.stiba.ac.id

terdapat Imam Abu Ja'far al-Ṭabarī (w. 310 H) yang menyusun kitab Jāmi' alBayān Fì Ta'wìl Āyi al-Qur'ān.

Perkembangan ini juga diikuti oleh Imam Ahmad, bahkan karena sudah "terlanjur kaya" dengan kondisi ini, sehingga disiplin ilmu apapun yang diinginkan maka pasti terpenuhi dan ulama yang menguasainya pun bertaburan. Dalam biografi Imam Ahmad dituliskan interaksinya dengan mazhab-mazhab fikih yang ada, antara lain beliau pernah berguru kepada al-Qāọi Abu Yusuf murid Imam Abu Hanīifah, kepada Sufyān bin 'Uyainah dan juga kepada Imam al-Syāif'‘'i. ${ }^{18}$

\section{Bentuk-bentuk Pandangan Fikih dan Usul Fikih Mazhab Ḥambali yang Lahir dari Latar Belakang Sosial.}

Dari pemaparan tentang latar belakang sosial pada era Imam Aḥmad tersebut, diperoleh secara lahiriah pandangan-pandangan fikih dan usul fikih Imam Ahmad yang berkaitan dengannya, antara lain:

\section{Hadis Mursal atau hadis yang diriwayatkan oleh tābi'ī dari Rasulullah saw. ${ }^{19}$ atau riwayat selain sahabat secara langsung dari Rasulullah saw. ${ }^{20}$}

Imam Ạ̣mad bin Hambal menerima hadis jenis ini secara mutlak pada saat mayoritas ulama fikih menolaknya jika bukan oleh täbi'i senior karena tidak memenuhi syarat hadis sahih, yaitu ketersambungan sanad. Hadis mursal di kalangan mayoritas ulama jika bukan riwayat tābi'i semisal Sa'id bin al-Musayyib atau al-Hasan al-Bașrī adalah termasuk dalam kategori hadis lemah (ḍa'î́f). Alasan yang disampaikan oleh Imam Ahmmad adalah karena ketersambungan sanad hingga kepada periwayat hadis yang saleh dan terpercaya masih lebih dapat diperpegangi dari daya nalar, karena lebih berdasar dari sekedar menalar. ${ }^{21}$ Hal ini jika dipandang dari sisi kondisi saat itu yang menunjukkan tersebarnya pemikiranpemikiran berbahaya atau tekanan pemerintah yang begitu represif terhadap pandangan Ahli sunah waljamaah khususnya di bidang teologi, merupakan pendapat yang benar.

\section{Berbilangnya pendapat Imam Ahmad dalam suatu permasalahan fikih}

Mazhab Hambali terkenal di dunia fikih sebagai mazhab yang memiliki pendapat lebih dari satu pada setiap permasalahan. Kadang-kadang dalam suatu permasalahan yang diperselisihkan oleh para fuqahā terdapat pendapat Imam

\footnotetext{
${ }^{18}$ Ismā’îil ibn 'Umar ibn Kaširir, al-Bidāyah, h. 359-361.

19، Abdurrahīm bin al-Ḥusain al-'Irāqi, al-Taqyīd wa al-Ị̂̂ạh Li Mā Uttliqa wa Ughliqa Min Muqaddimah Ibnu alSalạ̣̄ (Cet. II; Beirut: Muassasah al-Kutub al-Saqāfiyah, 1993), h. 71.

${ }^{20}$ Al-Qatṭān, op.cit., h. 390-391.

${ }^{21}$ Ibid.
} 
Aḥmad di setiap kelompok yang berbeda. Hingga di dalam mazhab Hambali sendiri terdapat buku-buku yang secara khusus membahas tentang pendapat fikih Imam Ahmad yang paling kuat dan benar, seperti buku karangan 'Ali bin Sulaymān al-Mardāwī (817-885 H) yang berjudul al-InșāfFī Ma'rifah al-Rājịh Min al-Khiläf 'Ala Mażhab al-Imām Ahmad bin Hambal. ${ }^{22}$

Menurut Dr. Mannā' al-Qaț̣ān hal, hal ini dikarenakan perubahan ijtihad Imam Aḥmad dalam suatu permasalahan, sehingga murid-muridnya menyampaikan berdasar pengetahuan mereka terhadap pendapat gurunya, atau sebab lain adalah sebagaimana yang diungkapkan oleh Ibnu al-Qayyim al-Jauziyah bahwa kadang-kadang Imam Ahmad meriwayatkan pendapat-pendapat sahabat Rasulullah saw. yang meskipun akhirnya Imam Ahmad memilih salah satu darinya sebagaimana prinsip dalam mazhab Hambali, namun murid-murid yang mendengarkannya terkadang menyimpulkan pilihan yang lain sehingga semua menyandarkannya kepada Imam Ahmad. ${ }^{23}$

Penyampaian (sebab) tersebut telah memberi gambaran pada semua bahwa kondisi sosial betapa pun itu turut andil pada pengaruh perkembangan mazhab. Terjadinya perubahan ijtihad adalah paling sering disebabkan oleh perubahan sosial masyarakat ('urf) dan biasanya adalah bersifat penerapan dalil. Sedangkan banyaknya aśar (pendapat-pendapat sahabat) yang disampaikan oleh Imam Ahmad menunjukkan kekayaan beliau terhadap sisi ini dalam setiap permasalahan dan hal itu disebabkan oleh berkembang dan mudahnya akses terhadap ilmu pengetahuan.

\section{KESIMPULAN}

Latar belakang sosial yang mempengaruhi lahirnya mazhab Hambali antara lain ialah dilatari oleh perselisihan teologis, kondisi politik dan perkembangan ilmu pengetahuan. Masing-masing dari sebab ini memiliki pengaruh terhadap hasil ijtihad Imam Ạ̣mad bin Hambal rahimahumullahu.Pengaruh dari kondisi sosial ini dapat ditelusuri dari pandangan-pandangan Imam Ạmmad bin Hambal khususnya di bidang fikih dan usul fikih. Seperti antara lain: Penggunaan hadis mursal sebagai salah satu prinsip dalam pola ijtihad beliau dan berbilangnya pendapat-pendapat beliau dalam suatu permasalahan fikih.

Adapun implikasi pada penelitian ini ialah daya transferbilitasnya dan atau dapat berkontribusi pada pengetahuan akan latar belakang sosial yang merupakan salah satu syarat ijtihad. Para ulama hendaknya menjaga kondisi sosial masyarakatnya, khususnya dalam penerapan dalil syar ${ }^{5} i$, sehingga pendapat-

${ }^{22}$ Muhammad Hamid al-Faqi, Muqaddimah Kitab al-Insaf fi Ma'rifah a-Rajih min al-Khilaf li al-Imam alMardawi (Cet.II; Beirut: Dar Ihya' al-Turas al-“Arabi, t.th), h. 3.

${ }^{23}$ Ibid., h. 393. 
BUSTANUL FUQAHA: Jurnal Bidang Hukum Islam

Vol. 1, No. 3 (2020) : Hal. 505-515

Website: https://journal.stiba.ac.id

pendapat fikih seorang ulama tidak boleh dilihat hanya dari pembahasan dalil syar'ì secara murni.

\section{DAFTAR PUSTAKA}

Al-'Ali Salih Ahmad. (2001). Muqaddimah Kitab Tarikh Baghdad li al-Imam alKhatib al-Baghdadi, Cet.I; Beirut: Dar al-Garb al-Islami,

Al-Ḥulaybì, Aḥmad bin 'Abd. al-'Azis. (1417 H). Uṣūl al-Hukm 'Alā alMubtadi'ah 'Inda Syaikh al-Islām Ibn Taimiyah, Jilid I, Cet. I; Doha: Wizārah al-Awqāf wa al-Syu'ūn al-Islāmiyah.

Al-Faqi, Muhammad Hamid. t.th. Muqaddimah Kitab al-Insaf fi Ma'rifah a-Rajih min al-Khilaf li al-Imam al-Mardawi, Cet.II; Beirut: Dar Ihya' al-Turas al-'Arabi.

Al-Fattūḥi, Muḥammad bin Aḥmad. (1413 H). Syarh al-Kawkab al-Munīr, Cet. II; Mekkah: Maṭābi’ Ummu al-Qurā.

Al-'Irāqi, 'Abdurrahīm bin al-Ḥusain. (1993). al-Taqyīd wa al-Ị̣̣̂̆ Li Mā Ut liqa wa Ughliqa Min Muqaddimah Ibnu al-Salāh, Cet. II; Beirut: Muassasah alKutub al- Ṡāāiyah.

Al-Jauziah, Ibnu Qayyim. (1417 H). I'lām al-Muwaqqi'inn 'An Rabb al-'Āamīn, Cet. II; Beirut: al-Maktabah al-'Așriyah.

Al-Juhanī, Māni' bin Hammād. (1418 H). al-Mawsū'ah al-Muyassarah fī al-Adyān wal Mażāhib wal Ahzāb al-Mu'āsirah, Cet. III; Riyāḍ: WAMY.

Al-Naisābūri, Muslim ibn al-Hajjāj. (1415 H). al-Ṣahīh Ma’a al-Nawawi, Cet. I; Beirut: Dār al- Kutub al-'Ilmiyah.

Al-Qaț̣ān, Mannā'. (1992). Tārikh al-Tasyrī' al-Islāmi, Cet. I; Riyāḍ: Maktabah al-Ma'ārif.

Departemen Agama Republik Indonesia. (1418 H). al-Qur'ān dan Terjemahnya, Medina: Mujamma' al-Malik Fahd li Ṭibā'at al-Mushaf al-Syarif.

Ibn Kas̄ir, Ismā'ìl ibn 'Umar. (t.th). al-Bidāyah wa al-Nihāyah, Beirut: Dār al-Ihyā al-Turāis al-'Arabi, 